\section{Dioxins and furans in breast milk: a case study of mothers from southern Rio de Janeiro, Brazil}

\author{
PCDD/Fs e dl-PCBs no leite materno. Estudo de \\ caso: parturientes de municípios pertencentes à \\ área industrial do Sul Fluminense, Brasil
}

\author{
PCDD/Fs y dl-PCBs en leche materna. Estudio de \\ caso: madres de municipios pertenecientes a la \\ zona industrial del sur de Río de Janeiro, Brasil
}

Aldo Pacheco Ferreira 1

Maria de Fátima Ramos Moreira ${ }^{1}$

\title{
Resumo
}

\footnotetext{
1 Escola Nacional de Saúde Pública Sergio Arouca

Fundação Oswaldo Cruz, Rio

de Janeiro, Brasil.

Correspondence

A. P. Ferreira

Centro de Estudos da Saúde

do Trabalhador e Ecologia

Humana, Escola Nacional de

Saúde Pública Sergio Arouca,

Fundação Oswaldo Cruz.

Rua Leopoldo Bulhões 1480 ,

Rio de Janeiro, $R J$

21041-210, Brasil.

aldopachecoferreira@gmail.com
}

\section{Abstract}




\section{Introduction}

Contaminations by polychlorinated dibenzo-pdioxins (PCDDs), polychlorinated dibenzofurans (PCDFs) and polychlorinated biphenyls (PCBs), closely related groups of chemical byproducts that are produced throughout the world and globally distributed in the environment, have been of great concern due to their endocrine disrupting effects on humans and wildlife ${ }^{1}$. Chemically stable and lipophilic properties of these contaminants led to their high contamination in higher trophic biota, including human ${ }^{2}$. Despite the intensive monitoring efforts and anticipated results of decreasing trends of persistent organic pollutants (POPs) in developed countries as a consequence of their regulation on use and waste treatment, little information is available on their contamination status in developing countries even though these chemicals are still being used and unintentionally produced in several parts of these countries.

Dioxins and furans are among the most hazardous chemicals known: extremely tiny doses have been shown to cause negative health effects ${ }^{3}$. These chemicals are listed by several governmental agencies as known causes of cancer in humans 4 . A small share of the dioxins and furans released into the environment are broken down by sunlight, but most persist by attaching to soil particles and sediment in water. Once attached to such particles, they enter the food chain, leading eventually to bioaccumulation in animal fat 5 . Indeed, studies have linked dioxins and furans to many adverse effects on human health, such as carcinogenicity, immunotoxicity and neurotoxicity 1,4. Dioxins and furans are attracted to fat, resistant to metabolism, and have a lipophilic nature which allows accumulation in human tissues ${ }^{6}$. Within the human body, the highest levels of these chemicals are in fat and breast milk. These compounds are lipid-soluble, poorly eliminated and are therefore accumulated and stored in human adipose tissues. They can pass through the placenta causing exposure of the foetus, and their existence in human milk exposes infants during the lactating period.

Human beings can be exposed to dioxins and furans in a number of ways. Eating contaminated food (primarily meat, dairy products, and fish) is the major path for dioxin exposure 3 , but other less common routes of exposure include contact with certain pesticides and herbicides (such as the wood preservative pentachlorophenol, and the phenoxy herbicides), or working in industries that produce dioxin and furan byproducts 7 .

Dietary exposure makes up more than 90 percent of human dioxin and furan intake 3 . Fatty foods usually contain more significant levels because they are higher up the food chain and thus have accumulated more dioxin. Once dioxins and furans have entered animal tissues, they have few opportunities to leave, so the chemicals can persist for many years. In lactating women, dioxins and furans may leave the body in breast milk. As with many other persistent chemicals that appear in breast milk, the concentration of dioxins and furans changes with time 8,9 .

In order to quantify the consumption by infants of the contaminants studied, their intake through breast milk was estimated. In fact, in many cases, since human milk is the only food that newborns consume in the first months of life, such an analysis makes it possible to estimate the intake of xenobiotics in a more simple and accurate manner than can be done in organisms with a more complex diet. In this study, the presence and levels of some classes of organochlorinated compounds were evaluated in samples of breast milk. In this paper data are presented on the levels of PCDD/Fs and dioxin-like PCBs in a pooled sample of breast milk from 27 mothers living at 12 locations in a meso-region industrial center of southern Rio de Janeiro, Brazil.

\section{Materials and methods}

\section{Sampling collection}

Human breast milk samples were collected from mothers living in 12 different areas of a meso-region industrial area (Angra dos Reis, Barra do Piraí, Barra Mansa, Itatiaia, Parati, Pinheiral, Piraí, Porto Real, Quatis, Resende, Rio Claro, Rio das Flores, Valença, and Volta Redonda), in southern Rio de Janeiro, between August 2012 and July 2013. A detailed questionnaire was given to obtain an informative record of the participants. Before giving milk, each mother completed an informed consent form. Breast milk samples were collected by manual expression and pooling of individual samples was done on a volume basis by taking $10 \mathrm{~mL}$ of collected milk from each donor so that a final volume of $270 \mathrm{~mL}$ was gathered. All samples were collected between four and six weeks after delivery.

\section{Sample preparation and extraction}

Fat extraction was performed using the BLH-IFF/ NT -30.05 method 7. The extraction of the human breast milk samples procedure followed the method described by Horii et al. ${ }^{8}$. 
Analysis

Gas chromatography (GC) analyses were performed on a CP-3800 GC equipped with a CP8400 autosampler (Varian Inc., Walnut Creek, USA). The toxic equivalency (TEQ) of the dioxin analogues in the analyzed samples was calculated using toxic equivalency factors (TEF) 9 .

\section{Results}

The donors ranged in age from 18 to 32 years (median: 23 years) and all 27 of them were primiparous. All mothers provided a detailed list of dietary habits. All donors had been living in the study area for at least five years before milk collection.

Tables 1 and 2 shows the levels of PCDD/Fs, and dl-PCBs congeners and total TEQs found in this pooled sample of mothers' milk from twelve locations related to the area under study. The average TEQs of PCDDs, PCDFs, dioxin-like PCBs were 10.6, 4.77, 6.96 TEQ pg/g fat.

\section{Discussion and conclusion}

Breast milk is the most complete food for newborns because its nutritional composition is essential for the physical and mental development of the child 5. Due to this sole source of food and the fact that at this stage many organs are still in development, newborns seem to be the group most vulnerable to organochlorinated compounds.

The participants' diet did not seem to differ much between the areas under study. It was a mixed diet with consumption of meat, fish, milk, and dairy products. The evaluation of the relationship obtained in questionnaires related to eating habits and its influence on breastfeeding and since we obtained positive results for PCDD/ Fs and dl-PCBs, no significant effect for babies was observed, as shown in Tables 1 and 2 .

A number of animal and human studies have looked at the health effects of dioxins and furans on children's health from in utero and postnatal exposure. Health outcomes that were evaluated have included low birth weight, hormone fluctuation, neurobehavioral function, and altered immune function ${ }^{9}$. Thus far, the studies have not identified any links between these health effects and exposure to dioxins specifically from breast milk.

Overall, the literature reviewed provides data on PCDD/Fs, and dl-PCBs in human milk in several countries. Compared to other studies in Bra-
Table 1

PCDD/Fs concentrations (pg/g fat) and total TEQs (TEQ $\mathrm{pg} / \mathrm{g}$ fat) in pooled breast milk samples from an industrial center. Rio de Janeiro, Brazil.

\begin{tabular}{|c|c|}
\hline Congener & $\mathrm{pg} / \mathrm{g}$ fat \\
\hline \multicolumn{2}{|l|}{ Dibenzo-p-dioxins (PCDD) } \\
\hline 2378-TCDD & 1.27 \\
\hline 12378-PeCDD & 6.19 \\
\hline 123478-HxCDD & 0.54 \\
\hline 123678-HxCDD & 22.47 \\
\hline 123789-HxCDD & 7.22 \\
\hline 1234678-HpCDD & 8.60 \\
\hline OCDD & 77.27 \\
\hline Total PCDDs TEQs & 10.60 \\
\hline \multicolumn{2}{|l|}{ Dibenzofurans (PCDF) } \\
\hline 2378-TCDF & 1.18 \\
\hline 12378-PeCDF & 0.49 \\
\hline 23478-PeCDF & 12.48 \\
\hline 123478-HxCDF & 3.31 \\
\hline 123678-HxCDF & 3.22 \\
\hline 1234789-HxCDF & 0.18 \\
\hline 234678-HxCDF & 2.02 \\
\hline 1234678-HpCDF & 1.99 \\
\hline 1234789-HpCDF & 0.00 \\
\hline OCDF & 0.73 \\
\hline Total PCDFs TEQs & 4.77 \\
\hline Total TEQs (PCDDs + PCDFs) & 15.37 \\
\hline
\end{tabular}

Table 2

dl-PCBs concentrations (pg/g fat) and total TEQs (TEQ pg/g fat) in pooled breast milk samples from an industrial center. Rio de Janeiro, Brazil.

\begin{tabular}{|c|c|}
\hline Congener & $\mathrm{pg} / \mathrm{g}$ fat \\
\hline \multicolumn{2}{|l|}{ Non-ortho PCBs } \\
\hline $3,3^{\prime}, 4,4^{\prime}-\mathrm{TCB}(77)$ & 36.50 \\
\hline $3,4,4^{\prime}, 5-\mathrm{TCB}(81)$ & 24.74 \\
\hline $3,3^{\prime}, 4,4^{\prime}, 5-\mathrm{PeCB}(126)$ & 60.70 \\
\hline $3,3^{\prime}, 4,4^{\prime}, 5,5^{\prime}-\mathrm{H} \times C B(169)$ & 38 \\
\hline \multicolumn{2}{|l|}{ Mono-ortho PCBs } \\
\hline $2^{\prime}, 3,4,4^{\prime}, 5-\mathrm{PeCB}(123)$ & 34.29 \\
\hline $2,3^{\prime}, 4,4^{\prime}, 5-\mathrm{PeCB}(118)$ & 9067 \\
\hline $2,3,3^{\prime}, 4,4^{\prime}-\mathrm{PeCB}(105)$ & 1,842 \\
\hline $2,3,4,4^{\prime}, 5-\mathrm{PeCB}(114)$ & 891 \\
\hline $2,3^{\prime}, 4,4^{\prime}, 5,5^{\prime}-\mathrm{H} \times C B(167)$ & 1,034 \\
\hline $2,3,3^{\prime}, 4,4^{\prime}, 5-\mathrm{HxCB}(156)$ & 2,897 \\
\hline $2,3,3^{\prime}, 4,4^{\prime}, 5^{\prime}-\mathrm{HxCB}(157)$ & 879 \\
\hline $2,3,3^{\prime}, 4,4^{\prime}, 5,5^{\prime}-\mathrm{HeCB}(189)$ & 249 \\
\hline Total dioxin-like PCBs TEQs & 6.96 \\
\hline Total dioxin TEQs & 22.33 \\
\hline
\end{tabular}


zil, our results were lower than those for mothers living in more industrialized countries $2,4,5,6$, but comparable to mothers in the city of Rio de Janeiro 10 .

A child who eats human milk is at the apex of the food chain and thus can receive a higher burden of contaminants eliminated by this pathway, especially those capable of undergoing the phenomenon of biomagnification 4,9. Children are particularly vulnerable to chemical agents present in the environment due to their physiological characteristics. Thus, dioxins, furans and polychlorinated biphenyls in air, water, soil, and food are more likely to be absorbed by children than for adults. Human milk is an important vehicle for elimination of xenobiotics from the body and may constitute a source of contamination for infants 6 .

PCDD/Fs and dl-PCBs bioaccumulation in the food chain has been shown to cause a number of toxic biological responses, which makes environmental and human exposure a focus for global concern. In particular, fish, meat, and milk are rich in dioxins due to their accumulation in tissue lipid. While the benefits of breastfeeding outweigh the risks from contaminants in human milk, it is extremely important to continuously identify these compounds in breast milk. In conclusion, this study suggests that it is important for pregnant women to have a balanced diet to mitigate the exposure of their infants to chemicals.

\section{Resumen}

Un estudio de PCDD/Fs y dl-PCBs se llevó a cabo en una muestra combinada de leche materna de 27 madres primíparas, residentes en 12 barrios que componen la zona industrial sur de Río de Janeiro, Brasil, entre agosto de 2012 y julio 2013. Se aplicaron cuestionarios con preguntas relacionadas con los hábitos alimentarios, condiciones socioeconómicas y lugares de vivienda. Se recogieron muestras de leche entre 4 y 6 semanas después del parto. Los niveles de PCDD/Fs y dl-PCBs fueron 10,6, 4,77 y 6,96 pg TEQ/g, respectivamente. La comprensión y la identificación de las fuentes de contaminación pueden ser útiles para la toma de medidas con- tra la contaminación por dioxinas en leche materna. Es importante que las mujeres embarazadas tengan un suministro lo más libre posible de contaminantes químicos. Deben llevarse a cabo más investigaciones para evaluar con mayor precisión los efectos de estos compuestos. La contaminación circunstancial por PCDD/ Fs y dl-PCBs en madres que viven en el área industrial de Río de Janeiro es inferior a la que generalmente se encuentra en los países industrializados.

Dioxinas; Furanos; Leche Humana; Exposición a Riesgos Ambientales 


\section{Contributors}

A. P. Ferreira contributed to the composition of the database, analysis and writing of the paper. M. F. R. Moreira helped in guiding the development and execution of the analysis, correction and writing of the paper.

\section{Acknowledgments}

Our thank to those responsible for laboratorial assistance and technical surveillance at the Oswaldo Cruz Foundation (Fiocruz), Rio de Janeiro Catholic University (PUC-Rio), and Rio de Janeiro Federal Rural University (UFRRJ).

\section{References}

1. Assunção J, Pesquero C. Dioxinas e furanos: origens e riscos. Rev Saúde Pública 1999; 33:523-30.

2. Barbieri H, Kiviranta H, Lindroos AK, Glynn A. Fish intake and breastfeeding time are associated with serum concentrations of organochlorines in a Swedish population. Environ Int 2013; 51:88-96.

3. Agency for Toxic Substances and Disease Registry. Toxicological profile for hexachlorocyclohexanes. Atlanta: Agency for Toxic Substances and Disease Registry; 2005.

4. Smith AG, Gangolli SD. Organochlorine chemicals in seafood: occurrence and health concerns. Food Chem Toxicol 2002; 40:767-79.

5. Gebremichael S, Birhanu T, Tessema DA. Analysis of organochlorine pesticide residues in human and cow's milk in the towns of Asendabo, Serbo and Jimma in South-Western Ethiopia. Chemosphere 2013; 90:1652-7.

6. Solomon GM, Weiss PM. Chemical contaminants in breast milk: time trends and regional variability. Environ Health Perspect 2002; 110:339-47.
7. Almeida JAG, Guimarães V, Novak FR. Normas técnicas para bancos de leite humano: coleta. Rio de Janeiro: Fundação Oswaldo Cruz; 2004.

8. Horii S, Sasamoto T, Otaka H. Improved analytical method for residual dioxins in human milk. Bull Environ Contam Toxicol 2003; 70:1121-7.

9. van den Berg M, Birnbaum LS, Denison M, De Vito M, Farland W, Feeley M, et al. The 2005 World Health Organization reevaluation of human and mammalian toxic equivalency factors for dioxins and dioxin-like compounds. Toxicol Sci 2006; 93:223-41.

10. Paumgartten FJR, Cruz CM, Chahoud I, Palavinskas R, Mathar W. PCDDs, PCDFs, PCBs, and other organochlorine compounds in human milk from Rio de Janeiro, Brazil. Environ Res 2000; 83:293-7.

Submitted on 02/Apr/2014

Final version resubmitted on 20/Feb/2015

Approved on 02/Mar/2015 